\title{
Using game theory approach to interpret stable policies for Iran's oil and gas common resources conflicts with Iraq and Qatar
}

\author{
Maryam Esmaeili $^{1} \cdot$ Aram Bahrini $^{2} \cdot$ Sepideh Shayanrad $^{1}$
}

Received: 11 September 2014 / Accepted: 21 July 2015/Published online: 4 August 2015

(C) The Author(s) 2015. This article is published with open access at Springerlink.com

\begin{abstract}
Oil and gas as the non-renewable resources are considered very valuable for the countries with petroleum economics. These resources are not only diffused equally around the world, but also they are common in some places which their neighbors often come into conflicts. Consequently, it is vital for those countries to manage their resource utilization. Lately, game theory was applied in conflict resolution of common resources, such as water, which is a proof of its efficacy and capability. This paper models the conflicts between Iran and its neighbors namely Qatar and Iraq between their oil and gas common resources using game theory approach. In other words, the future of these countries will be introduced and analyzed by some well-known $2 \times 2$ games to achieve a better perspective of their conflicts. Because of information inadequacy of the players, in addition to Nash Stability, various solution concepts are used based on the foresight, disimprovements, and knowledge of preferences. The results of mathematical models show how the countries could take a reasonable strategy to exploit their common resources.
\end{abstract}

Maryam Esmaeili

esmaeili_m@alzahra.ac.ir

Aram Bahrini

bahrini@ksu.edu

Sepideh Shayanrad

s.shayanrad@gmail.com

1 Department of Industrial Engineering, Alzahra University, Avesta Alley, Sheikh Bahaei Street, Vanak, Tehran, Iran

2 Department of Industrial and Manufacturing Systems Engineering, Kansas State University, Durland Hall, Manhattan 66506-5101, Kansas, USA
Keywords Conflict resolution - Non-cooperative game theory $\cdot$ Oil and gas common resources $\cdot$ Stability definitions

\section{Introduction}

The subject of common resources including oil and gas has become a crucial issue for countries such as Iran, which their economy depends greatly on revenues produced by oil and gas (Ilias 2008). The conflicts over common resources, faced by these countries, derive from not only the matters of benefits and costs, but also the social and political aspects of managing the resources.

Game theory can simply identify and explicate the behaviors of the parties involved in a conflict, without requiring a large number of data in hand. In fact, it is showed that the solutions provided by game theory are closer to practice in comparison with other common methods, due to better reflection of how involved parties behave in reality (Madani 2010). In the literature, game theory has applied to study the issues of common oil and gas resources with various purposes, including modeling, management and resolution.

Importing and exporting oil and gas have been modeled by game theory in the literature. For instance, the oil importing nations (OPIC) and the oil exporting nations (OPEC) are modeled as a two-person non-zero-sum game by Shenoy (1980a). Moreover, Shenoy (1980a) presents the non-cooperative and cooperative strategies to obtain the Nash and the von Neumann-Morgenstern negotiation solutions. Later, a three-person game is remodeled as cooperative concepts such as the Core, the Shapley value, the bargaining set and the Nucleolus which its players were the oil importing countries (OPIC), two groups in OPEC 
led by Iran and Saudi Arabia (Shenoy 1980b). Similar to Fishburn and Kochenberger (1979) and Friedman and Savage (1948), Reynolds (1999) described an alternative theory for OPEC behavior based on risk aversion utilizing a two-piece von Neumann-Morgenstern utility function. In addition, Massol and Tchung-Ming (2010) examined the development of cooperative policy between countries exporting Liquefied Natural Gas (LNG) and members of the Gas Exporting Countries Forum (GECF) to obtain Shapley Value and Nucleolus-inspired equilibria.

Moreover, the cooperative and non-cooperative strategies for the transit gas are studied by Schirillo (2006) and Zweifel et al. (2009). Grais and Zheng (1996) considered gas transit game as a three-player conflict including suppliers, transistors and importers under non-cooperative Stackelberg game. In 2003, the shippers' interaction on a gas transportation system was modeled as a two-stage game to obtain the Nash equilibria by Pagliero (2003). Later, two-stage games were also presented in pricing and the common property problems by DalleMule (2008) and Heintzelman et al. (2009).

Exploitation and production of the resources are studied as other important subjects in the oil and gas area. The resource extraction with $m$ hyperbolic players is modeled under a dynamic game by Nowak (2006). He assumed the Cobb-Douglas production by constructing a Markov subgame perfect equilibrium and analyzing the equilibrium path. Exploitation of common resources with social welfare function is the other discussing topic by consisting of games with finitely many players and a continuum of players by Wiszniewska-Matyszkiel (2008). Furthermore, the interaction between the oil consumers and the suppliers about the production strategy is discussed as a signaling game by Lin-lin and Zhong-ying (2008). They obtained the separating, pooling and hybrid equilibria in their model. Yang (2008) simulates strategic interactions between OPEC's decisions and ANWR (Alaskan Arctic National Wildlife Refuge) exploration as a dynamic game. Boyce and Vojtassak (2008) developed the theory of 'oil'igopoly exploration of resource based on predicting over-explore and Nash equilibrium level of exploration. Later Krasovskii et al. (2009) suggested a game-dynamic model of the operation of several interacting gas pipeline projects by modeling the current quantities of gas supply as approximations to Nash equilibrium points in the instantaneous "gas supply games". The study resulted in finding numerically Nash equilibrium commercialization policies for the entire group of the pipelines and using the model to analyze Caspian gas market. Castillo and Dorao (2013) introduced a decision-making framework based on game theory that simultaneously solves a multi-objective and multi-level decision making problem for the conceptual design and project evaluation in the oil and gas industry.
Game theory is also used in saving energy subject. For example, Magirou (1984) analyzed the process of national decision making about energy saving and fuel switching programs under non-cooperative policy as a non-zero-sum game. Afterward, strategic petroleum reserves were presented as a Markov game and a stochastic dynamic game to build up and draw down the policies by Fan and Zhang (2010) and Murphy and Oliveira (2010). Moreover, Aplak and Sogut (2013) evaluated a hybrid methodology consisting of fuzzy and game theoretic approaches for energy management decision making process. In this model, the players were defined as Industry and environment, and using MCDM methods their strategies were analyzed. The obtained hybrid method could be used in complex structures like sectors from production to consumption, and also energy intensive sectors.

Although oil and gas resources are studied from several perspectives in the literature, managing such vital resources not only requires a proper recognition of plans and objectives, but also necessitates the cognizance of limitations and conditions. For instance, Iran has a large number of joint fields on borders with Iraq, Kuwait, Saudi Arabia, Qatar, United Arab Emirates and Oman (Esrafili and Kiani 2011). The number of joint oil and gas fields in Iran is estimated near 28, including 18 oil fields, 4 gas fields and 6 oil and gas fields, which make Iran one of the few countries in the world who has this grand number of hydrocarbour resources (Mehr News 2011). But unfortunately, common field developments by Iran have been delayed due to various technical problems, contractual issues and recently politics (Johnson and Bruno 2012). While in the meantime, all the involved countries are outrunning Iran by rapidly developing and exploiting the fields without considering the irreversible repercussions. In fact the statistics provided by Organization of the Petroleum Exporting Countries bulletin (OPEC) on 2010-2011 (OPEC 2010-2011) show that the proportion of oil exportations to whole exportations for Iran, Qatar and Iraq is $85.4,40.6,98.2 \%$, respectively. Therefore, it is concluded that in spite of the great dependence of Iran's economy on oil exportation, Iran has not been able to profit from its numerous resources as well as other competing countries such as Qatar and Iraq.

Notwithstanding the research in theoretical aspects in common resource conflict (Gibbons 1992; Ostrom et al. 1994), the solution concepts are not yet well applied into real common resources confliction. Therefore, in this paper, it is attempted to illustrate the worthwhile utility of game theory in managing of Iran's common resource conflict. In other words, by presenting some famous games of oil and gas resources between Iran and its surrounding countries which share common resources, they would be able to make better decisions and, therefore, manage their resources more accurately. 
In the next section, a brief explanation of game theory and wide range of solution concepts are presented. In "Iran's oil and gas common resource management as noncooperative games" Iran's oil and gas conflicts with aforementioned countries are presented using well-known $2 \times 2$ games. Then, in "Advisable policies for each player in introduced games", most advisable policies for each player in separate games are offered to manage optimally their incomes and resources. Finally, conclusion and some suggestions for future works are presented.

\section{Game theory}

Game theory is a branch of mathematics, operations research and economics applied to study decision makers' behavior in conflict resolution. A conflict may arise when two or more agents with different objectives share the same system or resources (Krippendorff 1986). These agents may be individuals, groups, firms, or any combination of these (Turocy and Von Stengel 2001). A game is described as the interactions between players whose decisions affect the payoffs of others (Bahrini 2011). Game theory is defined by three specifications: the number of players, their strategies and their payoffs (Shor 2005a). Based on the payoffs of players, games are divided into two major categories, zero-sum games and non-zero-sum game. In zerosum games, whatever one player gains, the other player loses vice versa of non-zero-sum games. Non-zero-sum games better represent real-life situations that have more complications in the decision making process (Schneider 2001), and sometimes more potential for cooperation. Often, players will notice that their interests might at least sometimes be best served by not cooperating, or in other words swerving from the system's optimal solutions (Madani and Hipel 2011). In game theory, each player chooses a policy that optimizes his own objective. Therefore, this method is believed to be able to simulate the conflicts more realistically. Because in practice, the principal concern of players is to maximize their own benefits by making a decision which might not be beneficial to the whole system. These self-optimizing attitudes might provide non-cooperative behaviors from players, even when cooperative behavior is the best solution for all, and that is where game theory can be more powerful than other methods (Madani 2010).

Besides, the lack of availability of specific data which sometimes are inevitable does not bound game theoretical analyses. Through such analyses, not only the important aspects of the decision problem can be identified but also the participants can learn much through the approach and the point of view of game theory. Moreover, game theory provides us with the ability to analyze different situations from various aspects. It can contribute to achieve prosperity in international and political affairs, business, peace and war (Bahrini 2011).

To analyze the games, there are major characteristics for solution concepts, including foresight, willingness to disimprove and knowledge of preferences (Madani et al. 2011). The most commonly used solution concept in game theory is the well-known Nash stability (Madani and Hipel 2011). However, considering people's complicated attitudes, a solution concept like Nash might not be able to reflect the decisions of people with all kinds of characteristics (Bahrini 2011). Therefore, application of various solution concepts while analyzing a game might better reflect the game's outcomes (Madani and Hipel 2007). The games are analyzed using several stability definitions including the Nash stability $(R)$, General meta-rationality (GMR), Symmetric meta-rationality (SMR), Sequential stability (SEQ), Limited-move stability $\left(L_{\mathrm{h}}\right)$, and Nonmyopic stability (NM) which the main characteristics are briefly shown in Table 1 (for more details, see Madani and Hipel (2011)). In addition, some of the basic characteristics of a game such as dominant strategy, strictly dominant strategy, and Pareto optimal outcomes are investigated.
Table 1 Main characteristics of the stability definitions (Sheikhmohammady et al. 2011)

\begin{tabular}{|c|c|c|c|c|c|c|c|}
\hline \multirow[t]{2}{*}{ Characteristics } & \multirow[t]{2}{*}{ Sub-characteristics } & \multicolumn{6}{|c|}{ Stability definitions } \\
\hline & & Nash & GMR & SMR & SEQ & $L_{\mathrm{h}}$ & NM \\
\hline \multirow[t]{5}{*}{ Foresight } & Low (1 move) & $\boldsymbol{V}$ & & & & & \\
\hline & Medium (2 moves) & & $\checkmark$ & & $\boldsymbol{V}$ & & \\
\hline & Medium (3 moves) & & & $\boldsymbol{V}$ & & & \\
\hline & Variable ( $h$ moves) & & & & & $\boldsymbol{v}$ & \\
\hline & Unlimited & & & & & & $\boldsymbol{V}$ \\
\hline \multirow[t]{3}{*}{ Disimprovements } & Never & $\boldsymbol{V}$ & & & $\checkmark$ & & \\
\hline & By opponent & & $\checkmark$ & $\boldsymbol{V}$ & & & \\
\hline & Strategic & & & & & $\checkmark$ & $\boldsymbol{V}$ \\
\hline \multirow[t]{2}{*}{ Knowledge of preferences } & Own & $\boldsymbol{V}$ & $\checkmark$ & $\boldsymbol{V}$ & & & \\
\hline & All & & & & $\boldsymbol{V}$ & $\checkmark$ & $\boldsymbol{V}$ \\
\hline
\end{tabular}


Fig. 1 Geographical location of Iran-Qatar conflict over South Pars and North Dome common oil (EP-2010)

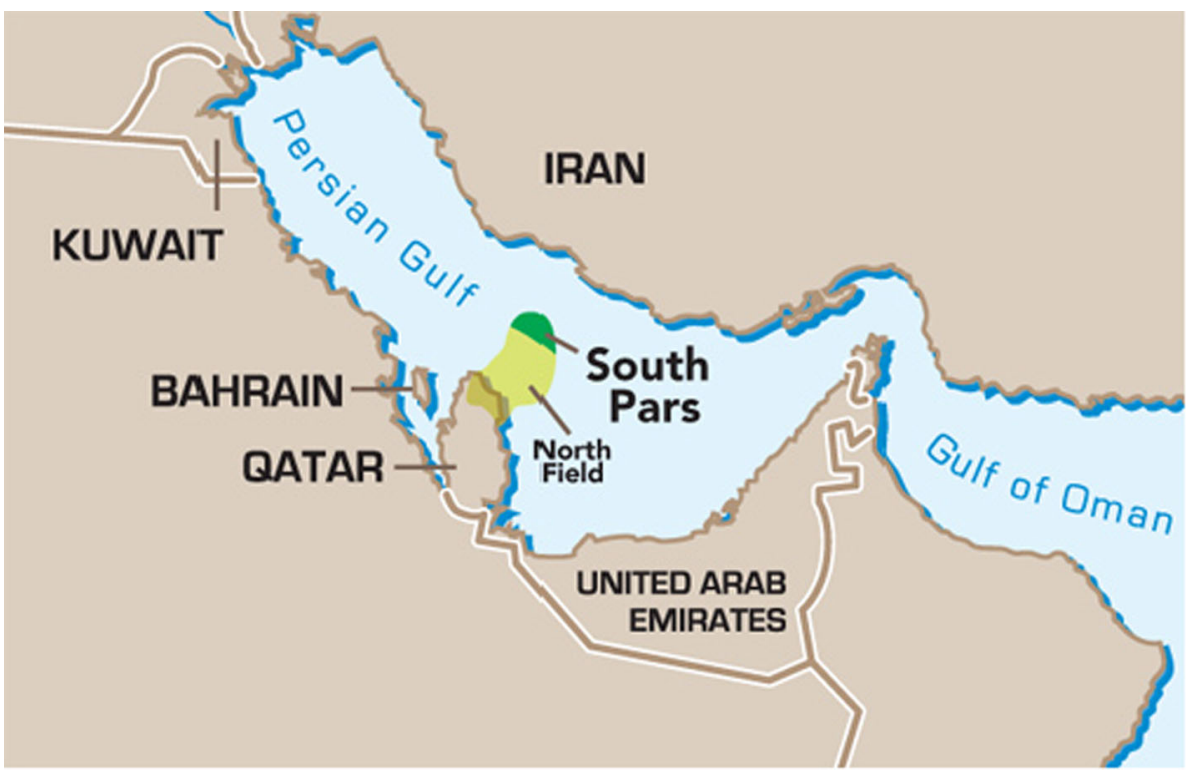

\section{Iran's oil and gas common resource management as non-cooperative games}

Because of many reasons such as the non-renewable structure of oil and gas resources, prediction of scientists about lack of resources in the near future, etc., oil and gas conflicts occurring in the real world are often complicated; therefore, it is indispensable to describe these complex models with less-complicated game theory models. However, using such simple models can lead to increased understanding of the real-world conflict in terms of its fundamental structure and strategic potentialities (Madani and Hipel 2011). In the following subsections, some famous $2 \times 2$ games are introduced, formulated, and solved. Additionally, the probable outcome of the conflicts is analyzed using a wide range of solution concepts and the results are discussed.

\section{Iran-Qatar conflict over South Pars and North Dome common oil field (Prisoner's Dilemma game)}

The Prisoner's Dilemma (PD) is one of the most famous strategic games in game theory. Its name comes from a story involving suspects in a crime. Its importance is due to various situations in which the parties have incentives similar to those faced by the suspects in prisoner's dilemma. In other words, different real-world conflicts of economic, social and even political aspects can appropriately be modeled by PD (Bahrini 2011). The conflict between Iran and Qatar over South Pars oil field at the present time (January, 2015) which is shown in Fig. 1 could be an example of coordination oil resource games. This field covers an area of 9700 square kilometers of which less than $40 \%$ is in Iranian territorial waters (South Pars) and the rest is in Qatari territorial waters (North Field or North Dome) (Chabrelie 2006). Qatar has started extraction of natural gas from the North Dome since 1991. With more than a decade of deferment, Iran started extraction in 2002. But unlike Qatar, Iran has not made much remarkable progress (IRAEE 2008).

As for the South Pars oil field, the situation is even more critical (Mehr News 2011). A few years ago (2009), Iran claimed that South Pars oil field is not a common field (Fars News Agency 2009) and, therefore, some deal it is not their first priority to develop it (BEDigest 2011; Mehr News 2011). At the present time (January, 2015), due to lack of international investment, contractual issues (Johnson and Bruno 2012) and also by not being provided with the adequate financial resources, Iran has the most retardation in the development of South Pars' common layers. On the other hand, Qatar has been able to make use of this field, and is extracting oil with the average of 700 thousand barrels per day (Tala News 2013). It is predicted that by completion of some of the development stages in the upcoming year, the extraction of this country from the oil layers of South Pars would reach up to 1 million barrels per day. At the same time, the share of Iran from this common oil field compared to Qatar is insignificant (Mehr News 2011).

During this period, the structure could be similar to a Prisoner's Dilemma. At first, countries might assume that the more they extract, the more they can gain; however, without having a long-term vision players may face various complications in future. If both countries extract at high extraction rates (HER), not only the oil levels would drop, but also the extracting costs would increase. In addition, it 
would reduce profit and ultimately lead into economic infeasibility of extraction (EBI 2003a). It is worth remembering that oil and gas exploration, extraction and production may leave negative impacts on ecosystems and biodiversity (EBI 2003b). But if both countries extract at a low extraction rate (LER), the oil level will not decrease and countries can enjoy long-term profits. In other words, cooperative extraction increases profits for both countries.

Qatar has achieved the best outcome which is getting a "free ride". In this case, the extraction costs are low compared to the state where both countries extract noncooperatively and the crop sale revenues are high in comparison with states where Qatar decides to cooperate. Alternatively, high extraction costs and low crop revenues lead to the lowest payoffs, if Qatar selects a cooperative policy while Iran does not wish to cooperate. Figure 2 represents the conflict in a normal form with cardinal payoffs. In this figure, the two rows and the two columns correspond to the two possible actions of Iran and Qatar, respectively. The numbers in each cell are the players' payoffs to the action profile to which the cell corresponds, with Iran's payoff listed first. A greater payoff indicates a higher utility for a player. It should be noted that the ordinal payoff in Fig. 2 is obtained based on the parametric form of model in the appendix (A). The outcomes of the game, considering different solution concepts, are shown in Table 2.

In this game, cooperative extraction (LER, LER) would provide both countries with more benefits which are

\begin{tabular}{|c|c|c|}
\hline & \multicolumn{2}{|c|}{ Qatar } \\
\hline & LER & $H E R$ \\
\hline LER & 2,2 & 0,3 \\
\hline HER & 3,0 & 1,1 \\
\hline
\end{tabular}

Fig. 2 Iran-Qatar conflict over South Pars and North Dome common oil field (PD game) socially efficient and Pareto optimal. States (LER, HER) and (HER, LER) in which Qatar and Iran are giving a free ride, respectively, are the worst outcome for each country. However, the cooperative resolution is Pareto optimal, which means that extraction by at least one player is the Pareto optimal solution. It is worth mentioning that a low extraction rate would keep the system survival. In addition, HER is a strictly dominant strategy for each player and (HER, HER) is a Pareto inferior outcome, a strictly dominant strategy equilibrium and the only Nash equilibrium of the game. The results show that according to all considered stability definitions, (HER, HER) is stable for the two players and is considered as an equilibrium for all the solution methods, although this state is not quite appropriate considering the payoffs of each party. (HER, LER) and (LER, HER) are stable under all the stability definitions only for one of the players (the one who is getting a free ride) and are never considered as equilibria. State (LER, LER) is Pareto optimal which is stable under all stability definitions except Nash. Therefore, only a shortsighted player would not recognize this stable state and any player who can see at least two moves (including the adversary's) is capable of such distinction. The states which are stable under more stability definitions have more chance in practical conflict resolution (Madani and Hipel 2011). Thus, (LER, LER) and (HER, HER) are the probable outcomes of such games.

In real conflicts, players often have wider foresight than what Nash stability predicts (Bahrini 2011). Consequently, state (LER, LER) provides the players with higher payoffs comparing to (HER, HER); thus, (LER, LER) is most likely to be the final outcome. State (LER, HER) is the status quo of the conflict in which Iran and Qatar are exploiting the oil field with a low and high extraction rate, respectively. Although the structure of the presented game is similar to PD, in this game the players are able to change their strategies repeatedly, unlike PD which is a one-move game (Madani and Hipel 2011). In the status quo, Qatar is getting a free ride from Iran which is desirable for Qatar.
Table 2 The results of stability analysis for the Iran-Qatar conflict

\begin{tabular}{|c|c|c|c|c|c|c|c|c|}
\hline \multirow[t]{3}{*}{ Stability definition } & \multirow{2}{*}{\multicolumn{2}{|c|}{$\begin{array}{l}\text { (LER, LER) } \\
\text { Stable for }\end{array}$}} & \multicolumn{2}{|c|}{ (LER, HER) } & \multicolumn{2}{|c|}{ (HER, LER) } & \multicolumn{2}{|c|}{ (HER, HER) } \\
\hline & & & & & & & & \\
\hline & Iran & Qatar & Iran & Qatar & Iran & Qatar & Iran & Qatar \\
\hline Nash (R) & & & & $v$ & $v$ & & $\checkmark$ & $v$ \\
\hline GMR & $v$ & $\checkmark$ & & $v$ & $v$ & & $v$ & $v$ \\
\hline SMR & $\checkmark$ & $\checkmark$ & & $\boldsymbol{v}$ & $\boldsymbol{v}$ & & $\boldsymbol{v}$ & $\checkmark$ \\
\hline SEQ & $\checkmark$ & $v$ & & $v$ & $v$ & & $v$ & $v$ \\
\hline$L_{2}$ & $\checkmark$ & $\checkmark$ & & $\boldsymbol{v}$ & $\boldsymbol{v}$ & & $\checkmark$ & $\checkmark$ \\
\hline$L_{3}$ & $\checkmark$ & $v$ & & $v$ & $v$ & & $v$ & $\checkmark$ \\
\hline Non-Myopic $\left(L_{4}\right)$ & $\checkmark$ & $\checkmark$ & & $\checkmark$ & $\boldsymbol{V}$ & & $\boldsymbol{V}$ & $\checkmark$ \\
\hline
\end{tabular}


This state would remain the best possible outcome for Qatar enjoying the benefits unless Iran implements a credible action to achieve a high rate extraction. Needless to mention that based on various solution concepts, (HER, LER) and (LER, HER) are not considered stable. As a result, the current state will not also be stable. On the other hand, Iran is making the least profit from the common oil resources in the current situation. Iran is better off considering the loss of benefits, therefore, change its policy and move from LER to HER. If Iran assigns more financial resources to exploitation and extraction, the game would be led towards (HER, HER). In that case, if countries are nonmyopic and aware of the payoffs, they would try to reach the state (LER, LER) to maximize their long-term benefits. To reach this state, both countries are required to shift from HER to LER simultaneously or else they would both end up in worse situations.

\section{Iran-Iraq conflict over well number four of Fakka field (Chicken game)}

Game of Chicken is a game in which two drivers driving towards each other at high speeds. Each player can either swerve (S) or drive straight (DS). The first one to swerve would be called the "chicken" for not having the courage to drive straight ahead and the other would be a proud winner. If none of them swerves, they would both suffer injuries or even die due to a fatal accident. It is supposed that when both drivers "chicken out", they drive in an opposite direction not leading to an accident (Madani and Hipel 2011). An example of an anti-coordination game could be the Iran-Iraq conflict on the well Number Four of the Fakka field (Fig. 3).

In 2009, border controversies were incited as Iraq started to sell development rights to fields like Fakka which are close to Iran's frontier (The New York Times 2009). After mentioned controversies, in December of 2009, Iraq announced that about ten Iranian soldiers have crossed the border, occupied well Number Four in Maysan Province in southeastern Iraq and flagged it (BBC News 2009). Iraq considered this act as an invasion and demanded immediate evacuation of the field. Iraq claimed to have dug oil wells on the Fakka field before the Iran-Iraq war, but Iran stated that the area near well Number Four occupied by its soldiers was a part of its own territory (Reuters 2009; The New York Times 2009). The Iraqi government declared that they were hoping to solve this problem diplomatically (Asr Iran 2009). Later that day, the Iranian troops withdrew. This withdrawal was followed by the entrance of Iraqi technicians to the well Number Four zone and initiation of the preliminaries of exploitation (RFI 2009). Although Iraq had said that they were not planning a military reaction, it is possible that if Iran had not left the

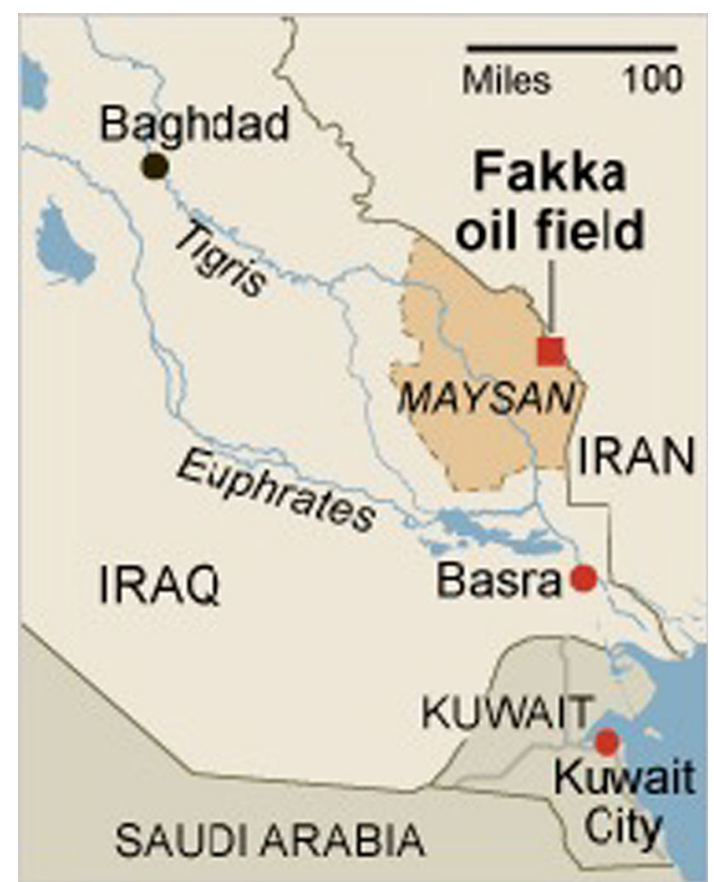

Fig. 3 The location of Fakka oil field on borders of Iran and Iraq (The New York Times 2009)

\begin{tabular}{|c|c|c|}
\hline & \multicolumn{2}{|c|}{ Iraq } \\
\hline & $C$ & $D$ \\
\hline \multirow{2}{*}{ Iran } & 3,3 & 2,4 \\
\hline & 4,2 & 1,1 \\
\hline
\end{tabular}

Fig. 4 Iran-Iraq conflict over well number four of Fakka field (Chicken game)

territory, or in other words "chickened out", it would have been considered as an option, especially with having in mind the history of Iran and Iraq including the border disputes between the two countries which set off the 1980-1988 Iran-Iraq war. As mentioned before, the structure of this conflict could be similar to a chicken game. Based on Fig. 4, each country can either Dare (D) or Chicken out (C). It should be noted that the ordinal payoff in Fig. 4 is obtained based on the parametric form of model in the appendix (B).

If both players select $(\mathrm{C}, \mathrm{C})$, they would leave the well unexploited and might reach a cooperative solution during further negotiations. By choosing $(C, D)$ or $(D, C)$, one of the countries would dare to exploit and benefit from the well, while the other would leave the area empty handed. However, if none of the countries chicken out and both decide to stick with the challenge, then it is possible that the rage heats up and leads to a catastrophic outcome, similar to the war of 1980s. State (D, D) produces the 
Table 3 The results of stability analysis for the Iran-Iraq conflict (chicken game)

\begin{tabular}{|c|c|c|c|c|c|c|c|c|}
\hline \multirow[t]{3}{*}{ Stability definition } & \multirow{2}{*}{\multicolumn{2}{|c|}{$\frac{(\mathrm{C}, \mathrm{C})}{\text { Stable for }}$}} & \multicolumn{2}{|c|}{$(\mathrm{C}, \mathrm{D})$} & \multicolumn{2}{|c|}{$(\mathrm{D}, \mathrm{C})$} & \multicolumn{2}{|c|}{$(\mathrm{D}, \mathrm{D})$} \\
\hline & & & & & & & & \\
\hline & Iran & Iraq & Iran & Iraq & Iran & Iraq & Iran & Iraq \\
\hline Nash $(R)$ & & & $\checkmark$ & $\checkmark$ & $\checkmark$ & $\boldsymbol{v}$ & & \\
\hline GMR & $\checkmark$ & $\boldsymbol{v}$ & $v$ & $v$ & $\checkmark$ & $\boldsymbol{v}$ & & \\
\hline SMR & $v$ & $v$ & $v$ & $v$ & $\boldsymbol{v}$ & $v$ & & \\
\hline SEQ & & & $v$ & $v$ & $\boldsymbol{v}$ & $\boldsymbol{v}$ & & \\
\hline$L_{2}$ & & & & $\boldsymbol{v}$ & $\boldsymbol{v}$ & & & \\
\hline$L_{3}$ & $\checkmark$ & $\boldsymbol{v}$ & & $\boldsymbol{v}$ & $\checkmark$ & & & \\
\hline Non-Myopic $\left(L_{4}\right)$ & $\checkmark$ & $\checkmark$ & & $\checkmark$ & $\checkmark$ & & & \\
\hline
\end{tabular}

lowest payoff for both countries and, therefore, they would rather not choose this strategy considering its high political, financial and mortal casualties.

The results in Table 3 show that state $(\mathrm{C}, \mathrm{C})$ is chosen by a player who considers possible disimprovements by the opponent player and possesses at least a two-level foresight (GMR) or a risk accepting player who allows strategic disimprovements and has at least a three-level foresight (SMR, $L_{3}$ and $L_{4}$ ). A state in which one country dares and the other chickens out is considered stable based on all the applied solution concepts, even by a shortsighted player not aware of the opponent's preferences. For this game, due to its anti-coordination structure, at least one of the parties will chicken out. All the above states are Pareto optimal except state (D, D) which is never selected by players. However, there is no dominant or even strictly dominant strategy in the aforementioned chicken game.

If countries resemble in behaviors, meaning they both have a high risk tolerance and take disimprovements into account, therefore, they both decide to chicken out [state $(\mathrm{C}, \mathrm{C})]$ and postpone their compromises for further bargains, which is likely to be an outcome of the game. Having the characteristics defined by Nash, players often disregard the possibility of cooperation. In that case, one player will definitely get a free ride. But such a stable state is not regarded as equilibrium for a risk accepting player who considers strategic disimprovements. Moreover, countries are not motivated to select (D, D) as a possible outcome, bearing in mind the disastrous results of the probable dispute.

As it was mentioned before, in this conflict Iran decided to give a free ride. In reality, parties may be involved in various conflicts simultaneously. Giving a free ride may not always mean giving up on benefits. Sometimes, countries prefer to overlook a privilege, intending to attain a more crucial concession such as national security, environmental protection, etc.

\section{Iran-Iraq conflict over common oil and gas resources (Stag-Hunt game)}

Stag-Hunt (also known as the Trust Dilemma) is a game in which two hunters go out on a hunt. Each player has two options. He can choose to hunt a stag or a hare. Each hunter can hunt a hare by himself, but if hunting a stag is desired, the cooperation of his partner is demanded. Hunting a hare may be tempting, knowing that it is easier to catch. On the other side, hunting a stag which is quite large and, therefore, challenging requires mutual cooperation (Shor 2005b).

An oil and gas resource example with a stag-hunt structure is shown in Fig. 5. It is worth mentioning that, LER and MER stand for low extraction rate and maximum extraction rate, respectively. It should be considered that the ordinal payoff in Fig. 5 is obtained based on the parametric form of model in the appendix (C).

This game is the predicted situation between Iran and Iraq considering their oil and gas common fields. So far, around twenty oil and gas fields have been identified on the borders of Iran and Iraq and most of them are said to be common fields between the two countries (Mehr News 2010). It is estimated that twelve out of these joint fields are common oil fields, from which Iraq's extraction rate is said to be 295 thousand barrels per day. That is more than twice Iran's extraction rate (130 thousand barrels per day) (Mehr News 2011).

\begin{tabular}{|c|c|c|}
\hline & \multicolumn{2}{|c|}{ Iraq } \\
\hline & $L E R$ & MER \\
\hline$L E R$ & 3,3 & 0,2 \\
\hline MER & 2,0 & 1,1 \\
\hline
\end{tabular}

Fig. 5 Iran-Iraq conflict over common oil and gas resources (StagHunt game) 
After the invasion of Iraq in 2003, the newly formed Iraqi government decided to augment its oil production by awarding considerable contracts to the major oil companies of the world (CNN 2011). That was when the Iranian officials were warned about the possibility of the migration of Iranian oil from the joint oil fields to Iraq.

One of the few solutions suggested to Iran to prevent this wasteful migration was for both countries to start operating the joint oil fields simultaneously (Mehr News 2010). But even this solution will probably not be able to resolve the issue completely. If there are several operators for a joint oil field, each would try to reach the highest production rate of oil in the shortest time possible. Under such circumstances, since the main focus is on maximizing production, the maintenance of the oil field and production optimization would at least be partly disregarded. Such a policy would damage the entire field to the point where the interests of all the parties are harmed (Mehr News 2010). In January 2011, the two countries announced that in order to increase their crude output, they have reached an agreement to develop joint oil fields on border areas (Press TV News 2012b). If they both exploit the fields with an equal and reasonable extraction rate which is less than the maximum rate possible, the conditions of the fields are monitored more accurately; thus, the long-term benefits of proper maintenance of the fields exceed the revenue losses from extracting less than maximum.

However, if only one country exploits the fields trying to maximize its production, the fields may not be damaged entirely, but their long-term benefits would be minimal, and the other country's payoff would decrease because of the revenue losses from a lower extraction rate. This is similar to the current conditions (January, 2015) of Iran and Iraq, in which Iraq is the one country who is exploiting the fields intending to maximize its production. If countries intend to profit from the long-term benefits of the resource, they are obliged to exploit the fields with an appropriate low extraction rate (LER) which leads to the outcome (LER, LER). Game theory presents this suitable outcome as equilibrium of the game according to all the applied solution concepts (see Table 4).
Choosing the cooperative policy LER is similar to hunting a stag which is more difficult to hunt requiring the other player's cooperation, but in fact leads to more benefits.

Moreover, results show that though the Pareto optimal resolution (LER, LER) is considered as an equilibrium, if players are shortsighted and not equipped with the ability to risk, they might both choose to exploit the fields with the maximum extraction rate (MER), introducing state (MER, MER) which is another equilibrium for the game. Such outcome has the potential to endanger the non-renewable resource to the point of its complete deterioration. In this game, similar to PD game, the cooperative resolution is Pareto optimal. Moreover, like the chicken game, there are neither dominant nor strictly dominant strategies for this conflict. However, since players cooperate during the staghunt game, state (LER, LER) is considered Pareto optimal.

Only based on GMR and SMR solution concepts, states (LER, MER) and (LER, HER) in which one country chooses not to cooperate are considered stable for the country who is profiting more. Therefore, these states are not considered as equilibria and predictable outcomes of the game. Based on the previous explanations, the state in which Iran and Iraq are extracting with a low and maximum extraction rate, respectively, is not stable. Therefore, the status quo of the game (LER, MER) would not a probable outcome. The best solution for Iran which is also the best outcome of the game is to convince Iraq to decrease its extraction and shift from MER to LER. But Iraq might not agree to cooperate with Iran due to its other national or international concerns. In that case, increasing the extraction rate and shifting from LER to MER would provide Iran with more benefits. It is worth mentioning that strategies selected by players in a stag-hunt game are deeply affected by mutual trust which can be attained in repeated games. Players will definitely choose the cooperative policy by knowing that the other player is trustworthy or by receiving cooperative signals. Some basic characteristics of the presented games in "Iran's oil and gas
Table 4 The results of stability analysis for the Iran-Iraq conflict (Stag-Hunt game)

\begin{tabular}{|c|c|c|c|c|c|c|c|c|}
\hline \multirow[t]{3}{*}{ Stability definition } & \multirow{2}{*}{\multicolumn{2}{|c|}{$\frac{\text { (LER, LER) }}{\text { Stable for }}$}} & \multicolumn{2}{|c|}{ (LER, MER) } & \multicolumn{2}{|c|}{ (MER, LER) } & \multicolumn{2}{|c|}{ (MER, MER) } \\
\hline & & & & & & & & \\
\hline & Iran & Iraq & Iran & Iraq & Iran & Iraq & Iran & Iraq \\
\hline $\operatorname{Nash}(\mathrm{R})$ & $\checkmark$ & $\checkmark$ & & & & & $\checkmark$ & $\checkmark$ \\
\hline GMR & $\checkmark$ & $\checkmark$ & & $\checkmark$ & $\checkmark$ & & $\checkmark$ & $\boldsymbol{V}$ \\
\hline SMR & $\checkmark$ & $\checkmark$ & & $\checkmark$ & $\checkmark$ & & $\checkmark$ & $\boldsymbol{V}$ \\
\hline SEQ & $\checkmark$ & $\checkmark$ & & & & & $\checkmark$ & $\boldsymbol{V}$ \\
\hline$L_{2}$ & $\checkmark$ & $\checkmark$ & & & & & & \\
\hline$L_{3}$ & $\checkmark$ & $\checkmark$ & & & & & & \\
\hline Non-Myopic $\left(L_{4}\right)$ & $\checkmark$ & $\checkmark$ & & & & & & \\
\hline
\end{tabular}


Table 5 Characteristics of the introduced games

\begin{tabular}{llll}
\hline Game & $\begin{array}{l}\text { Iran-Qatar game } \\
\text { (Prisoner's Dilemma) }\end{array}$ & $\begin{array}{l}\text { Iran-Iraq game } \\
\text { (chicken game) }\end{array}$ & $\begin{array}{l}\text { Iran-Iraq game } \\
\text { (Stag-Hunt game) }\end{array}$ \\
\hline Characteristics & & & - \\
Dominant strategy & HER & - & - \\
Strictly dominant strategy & HER & - & - \\
Strictly dominant strategy equilibrium & (HER, HER) & (C, C), (C, D), (D, C) & (LER, LER) \\
Pareto optimal outcome & (LER, HER), (HER, LER), (LER, LER) & Anti-coordination game & Coordination game \\
Classification & Coordination game & &
\end{tabular}

common resource management as non-cooperative games" are summarized in Table 5.

\section{Advisable policies for each player in introduced games}

There are several advices for the players in aforementioned games that will be explained in this section separately.

\section{Iran-Qatar conflict over South Pars and North Dome common oil field}

\section{Iran: changing its strategy from LER to HER}

Based on this assumption, which is (HER, HER), Iran should negotiate and attempt to set up an agreement with Qatar to decline the extraction rate simultaneously.

Qatar: continuing exploitation with a maximum extraction rate.

This condition is ideal for Qatar as long as Iran extracts with a low rate. Forasmuch as the current situation is not stable, it is appropriate for Qatar to change its policy to LER when Iran moves from LER to MER.

According to unexpected incomes from extraction the resources, it is worth mentioning that Qatar must not change its policy as soon as Iran change its extraction rate from low to maximum.

\section{Iran-Iraq conflict over well number four of Fakka field}

Iran: intending to manage a more fundamental concession such as national security, environmental protection, etc

Since Iran gives a free ride to Iraq and chickened out in this conflict, as it mentioned before, giving a free ride may not always means giving up on benefits. It might be vital for Iran to overcome the abovementioned priorities instead of involving in conflicts with Iraq. This action might justify leaving some of oil fields unexploited. Bearing in mind that if Iran try to change its policy to Dare (D), its payoff decreases from 2 to 1 . Iran might be able to convince Iraq to chicken out and in this condition Iran can exploit the fields in a more suitable situation.

Iraq: joying of long-term benefits from exploitation of Fakka field without any disruption by Iran

In addition to joying long-time benefits, it is necessary for Iraq to stabilize the current situation.

\section{Iran-Iraq conflict over common oil and gas resources}

Iran: increasing extraction rate to maximum

Since the status quo of the game is low extraction rate by Iran and maximum extraction rate for Iraq, by ignoring the potential endangerment of the resources, Iran should increase its extraction rate to maximum. Based on this assumption, which is (MER, MER), the payoffs of the players will be very low. After that change, it is best for Iran to negotiate and try to set up an agreement with Iraq to turn down the extraction rate together. In this aforementioned state, both countries can achieve the highest payoff and can profit from the long-term benefits of the resources. It is worth remembering that the current situation is not stable and it is not a predictable outcome of this conflict.

Iraq: altering strategy from MER to LER

Because the payoff of Iraq will progress and this country can enjoy from the long-term benefits. Moreover, the state in which Iraq decide to extract at a low rate is a Pareto optimal and moving to this state can improve political and also economic relationships between Iran and Iraq. However, Iraq should consider that the current situation (LER, MER) will not remain stable. 
Taking everything into consideration, unfortunately, the outcomes show that despite the measures taken by other countries, Iran has not been able to make effectual and winning decisions. In this case, Iran would be better off representing a more accurate image to the international community by developing and improving terms with countries in the region, therefore, obviating the problems of oil and gas field development such as sanctions and profiting from the benefits of these resources equally as the adversaries.

\section{Conclusion}

Managing use of non-renewable resources such as oil and gas is very important for the countries that their economics depends on petroleum. Particularly, it would be crucial when the resources are common with their neighbors. It is worth mentioning that developing a model with the ability to simulate the real-world conflicts in detail is almost impossible. To achieve a better perception of real-world conflicts, modeling the games and analyzing them can provide new insights.

In this paper, Iran's conflict with Qatar and Iraq which share oil and gas common resources is modeled based on game theory approach. Developed models are analyzed and performed by considering different solution concepts that led to a more comprehensive perspective of Iran's conflicts. The results can be applied as useful means for oil and gas common resources' management and conflict resolution. Thus, based on recommendation to the players, the countries could select a reasonable policy to exploit their common resources.

There is much scope in extending the present study. For example, the existence of signals in the models can be considered in the presented conflicts. Furthermore, in the real-world problems, there are more players and also there exist more options in the game. Considering these kinds of limitations can present the predictions more realistic. Additionally, the interconnection of Iran and Iraq games can be taken into account for further researches.

Acknowledgements The authors would like to thank Mohsen Shayan and Nima Salehi Sadghiani because of their editorial comments to this study and article proof reading. In addition, we would like to thank the anonymous reviewers for their helpful comments that greatly contributed to improving the final version of the paper.

Open Access This article is distributed under the terms of the Creative Commons Attribution 4.0 International License (http://crea tivecommons.org/licenses/by/4.0/), which permits unrestricted use, distribution, and reproduction in any medium, provided you give appropriate credit to the original author(s) and the source, provide a link to the Creative Commons license, and indicate if changes were made.

\section{Appendix}

Regarding chosen strategy of the players, Cournot model and market elasticity, the parametric form of each model is as follows:

(A) Prisoner's dilemma parametric form:

$$
\begin{aligned}
& P=K-Q_{\text {Iran }}-Q_{\text {Qatar }} \\
& \text { 1) } Q(\text { LER })<\quad Q(H E R) \\
& \text { 2) } P(H E R, H E R)<P(H E R, L E R) \\
& =P(\text { LER }, \text { HER }) \quad<P(L E R, L E R) \\
& \text { 3) }\left\{\begin{array}{l}
(P(L E R, H E R)-C) Q(H E R)>(P(\text { LER }, \text { LER }) \\
-C) Q(\text { LER })>(P(H E R, H E R)-C) Q(H E R)> \\
(P(\text { LER }, H E R)-C) Q(\text { LER })
\end{array}\right.
\end{aligned}
$$

where $P$ is the Price, $K$ is the Market elasticity, $\mathrm{Q}_{\text {Iran }}$ is the Iran's oil extraction, and $Q_{Q}$ atar is the Qatar's oil extraction, $\mathrm{P}(i, j)$. The price when the first and the second players choose $i$ and $j$, respectively $(i=\mathrm{LER}, \mathrm{MER} ; j=\mathrm{LER}, M E R) . \mathrm{C}=$ Set up cost.

(B) Chicken game parametric form:

$P=K-Q_{\text {Iran }}-Q_{\text {Iraq }}$

1) $Q(C)<Q(D)$

2) $P(D, D)<P(C, D)=P(D, C)<P(C, C)$

3) $(P(C, D)-C) Q(D)>(P(C, C)-C) Q(C)$

$$
>(P(C, D)-C) Q(C)>(P(D, D)-C) Q(D)
$$

where $P$ is the Price, $K$ is the Market elasticity, $\mathrm{Q}_{\text {Iran }}$ is the Iran's exploitation, and $\mathrm{Q}_{\text {Iraq }}$ is the Iraq's exploitation, $P(i, j)=$ The price when the first and the second players choose $i$ and $j$, respectively $(i=\mathrm{C}, \mathrm{D} ; j=\mathrm{C}, \mathrm{D}) . C=$ Set up cost.

(C) Stag-Hunt game parametric form

$$
\begin{aligned}
P= & K-Q_{\text {Iran }}-Q_{\text {Iraq }} \\
\text { 1) } & Q(L E R)<Q(M E R) \\
\text { 2) } & P(M E R, M E R)<P(M E R, L E R)=P(L E R, M E R) \\
& <P(L E R, L E R) \\
\text { 3) } & P(L E R, L E R) Q(L E R)>P(L E R, M E R) Q(M E R)
\end{aligned}
$$

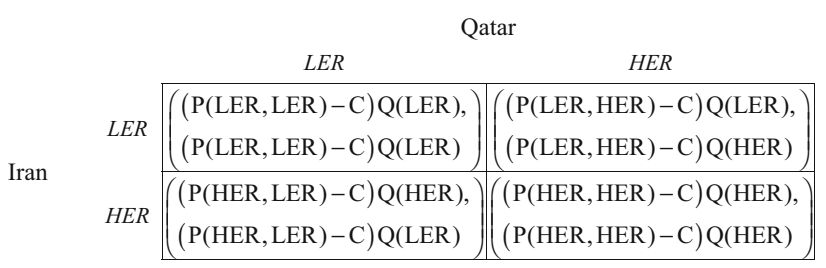

Fig. 6 Parametric form of Iran-Qatar conflict over South Pars and North Dome common oil field (PD game) 


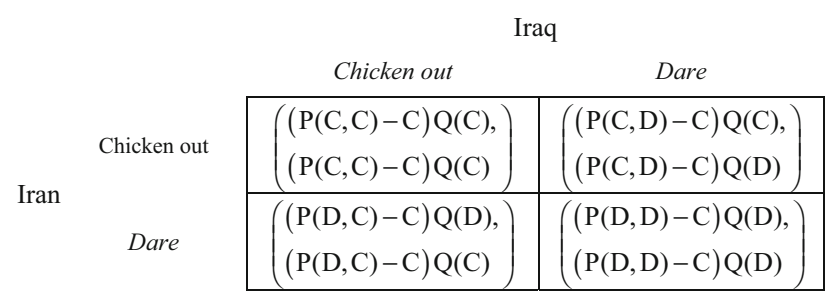

Fig. 7 Parametric form of Iran-Iraq conflict over well number four of Fakka field (Chicken game)

\begin{tabular}{|c|c|c|}
\hline & \multicolumn{2}{|c|}{ Iraq } \\
\hline & LER & $M E R$ \\
\hline$L E R$ & $\left(\begin{array}{l}(\mathrm{P}(\mathrm{LER}, \mathrm{LER})-\mathrm{C}) \mathrm{Q}(\mathrm{LER}) \\
(\mathrm{P}(\mathrm{LER}, \mathrm{LER})-\mathrm{C}) \mathrm{Q}(\mathrm{LER})\end{array}\right.$ & $\left(\begin{array}{l}(\mathrm{P}(\mathrm{LER}, \mathrm{MER})-\mathrm{C}) \mathrm{Q}(\mathrm{LER}), \\
(\mathrm{P}(\mathrm{LER}, \mathrm{MER})-\mathrm{C}) \mathrm{Q}(\mathrm{MER})\end{array}\right.$ \\
\hline$M E R$ & $\left(\begin{array}{l}(\mathrm{P}(\mathrm{MER}, \mathrm{LER})-\mathrm{C}) \mathrm{Q}(\mathrm{MER}), \\
(\mathrm{P}(\mathrm{MER}, \mathrm{LER})-\mathrm{C}) \mathrm{Q}(\mathrm{LER})\end{array}\right.$ & $\begin{array}{l}(\mathrm{P}(\mathrm{MER}, \mathrm{MER})-\mathrm{C}) \mathrm{Q}(\mathrm{MER}), \\
(\mathrm{P}(\mathrm{MER}, \mathrm{MER})-\mathrm{C}) \mathrm{Q}(\mathrm{MER})\end{array}$ \\
\hline
\end{tabular}

Fig. 8 Parametric form of Iran-Iraq conflict over common oil and gas resources (Stag-Hunt game)

where $P$ is the Price, $K$ is the Market elasticity, $\mathrm{Q}_{\text {Iran }}$ is the Iran's oil and gas extraction, and $\mathrm{Q}_{\text {Iraq }}$ is the Iraq's oil and gas extraction, $P(i, j)=$ The price when the first and the second players choose $i$ and $j$, respectively $(i=\mathrm{LER}, \mathrm{MER} ; j=\mathrm{LER}, \mathrm{MER})$. $C=$ Set up cost (Figs. 6, 7, 8).

\section{References}

Aplak HS, Sogut MZ (2013) Game theory approach in decisional process of energy management for industrial sector. Energy Convers Manag 74(2013):70-80

Asr Iran (2009). Boundary lines are conditioned by Iraq for Iran: Retreat from Alpha Coronae Borealis!. Viewed on January 20, 2015. http://www.asriran.com/fa/news/97062/\%D8\%B9\%D8\% B1\%D8\%A7\%D9\%82-\%D8\%A8\%D8\%B1\%D8\%A7\%DB\%8C -\%D9\%85\%DB\%8C\%D9\%84\%D9\%87-\%DA\%AF\%D8\%B0\% D8\%A7\%D8\%B1\%DB\%8C-\%D9\%85\%D8\%B1\%D8\%B2\%DB \%8C-\%D8\%A8\%D8\%A7-\%D8\%A7\%DB\%8C\%D8\%B1\%D8 \%A7\%D9\%86-\%D8\%B4\%D8\%B1\%D8\%B7-\%DA\%AF\%D8\% B0\%D8\%A7\%D8\%B4\%D8\%AA-\%D8\%B9\%D9\%82\%D8\%A 8-\%D9\%86\%D8\%B4\%DB\%8C\%D9\%86\%DB\%8C-\%D8\%A7 \%D8\%B2-\%D9\%81\%DA\%A9\%D9\%87 (In Persian)

Bahrini A (2011). Strategic Analysis of the players in Common Pool Resources using Game Theory. M.Sc. Thesis, Department of Industrial Engineering, K. N. Toosi University of Technology, Iran, September 2011. (In Persian)

BBC News-British Broadcasting Corporation (2009). Iran troops 'seize Iraq oil well. Viewed on March 27, 2012. http://news.bbc. co.uk/go/pr/fr/-/2/hi/middle_east/8420774.stm

BEDigest-Business and Economics Digest (2011). Chinese firm warned over Iran's South Pars delay. Viewed on April 22, 2012. http://www.bedigest.com/NEWS/59243.aspx

Boyce JR, Vojtassak L (2008) An'oil'igopoly theory of exploration. Resour Energy Econ 30(3):428-454
Castillo L, Dorao CA (2013) Decision-making in the oil and gas projects based on game theory: Conceptual process design. Energy Convers Manag 66(2013):48-55

Chabrelie MF (2006). Current status of the World's gas giants. International Gas Union (IGU), WOC 1 Exploration and Production of Natural Gas-SG1.1, 6, viewed on September 5, 2012. http://www.igu.org/html/wgc2006pres/data/wgcppt/pdf/WOC\% 20Working\%20Committees/WOC\%201/The\%20worlds\%20most $\% 20$ significant $\% 20$ gas\%20fields/1.1CS.03.pdf

CNN-Cable News Network (2011). Iraq oil starting to come on strong. By Hargreaves, S., CNN Money, viewed on April 3, 2012. http://money.cnn.com/2011/10/28/news/international/ iraq_oil/index.htm

DalleMule LL (2008) Implications and effectiveness of iterated pricing games in the Brazilian retail market. J Revenue Pricing Manag 7(2):128-138. http://www.palgrave-journals.com/rpm/ journal/v7/n2/pdf/rpm20081a.pdf. Accessed 3 Jan 2012

EBI-The Energy and Biodiversity Initiative (2003a). Negative secondary impacts from Oil and Gas Development, the Energy and Biodiversity initiative. Discussion paper, 5-6. Viewed on June 12, 2012. http://www.theebi.org/pdfs/impacts.pdf

EBI-The Energy and Biodiversity Initiative (2003b). Integrating Biodiversity Conservation into Oil and Gas Development, The Energy and Biodiversity Initiative. Discussion paper, 1. Viewed on June 12, 2012. http://www.theebi.org/pdfs/ebi_report.pdf

EP-Exploration and Production (2010). Special report: Iran leaps into South Pars. By Amini M.S., viewed on March 27, 2012. http:// www.epmag.com/Production-Drilling/Special-Report-Iran-leapsSouth-Pars_71905. Figure source http://www.epmag.com/Maga zine/2010/11/Images/spcreport_SouthParsFIELD_img1.jpg

Esrafili B, Kiani F (2011) Persia land of black gold. GEOEXPRO Magazine 8(6). http://www.geoexpro.com/articles/2012/04/per sia-land-of-black-gold

Fan Y, Zhang XB (2010) Modeling the strategic petroleum reserves of China and India by a stochastic dynamic game. J Policy Modeling 32(4):505-519

Fars News Agency (2009) The oil layers of South Pars are not common. http://www.farsnews.com/newstext.php?nn=8807220 541. Accessed 22 April 2012 (In Persian)

Fishburn PC, Kochenberger GA (1979) Two-Piece Von NeumannMorgenstern utility functions. Decis Sci 10(4):503-518

Friedman M, Savage LJ (1948) The Utility analysis of choices involving risk. J Political Econ 56(4):279-304

Gibbons R (1992) Game theory for applied economics. New Jersey Press, Princeton

Grais W, Zheng K (1996) Strategic interdependence in European East-West gas trade: a Hierarchical Stackelberg game approach. Energy J 17(3):61-84

Heintzelman M, Salant SW, Schott S (2009) Putting free-riding to work: a partnership solution to the common-property problem. J Environ Econ Manag 57(3):309-320

Ilias S (2008). Iran's Economy. Congressional Research Service (CRS) Report for Congress, 15-16, updated on June 2008, viewed on January 5, 2012. http://www.parstimes.com/history/ crs_economy_08.pdf

IRAEE-Iranian Association for Energy Economics (2008) The latest report of natural gas production by Iran and Qatar. J Energy Econ 110:18-19 In Persian

Johnson T, Bruno G (2012). The Lengthening List of Iran Sanctions. CFR-Council on Foreign Relations, viewed on April 22, 2012. http://www.cfr.org/iran/lengthening-list-iransanctions/p20258\#p3

Krasovskii AA, Matrosov IV, Tarasyev AM (2009) Optimal timing control in game modeling of an energy project infrastructure. Nonlinear Anal Theory Methods Appl 71(12):e2498-e2506 
Krippendorff K (1986). A Dictionary of Cybernetics. Unpublished Report, retrieved on March 5, 2012. http://cleamc11.vub.ac.be/ ASC/GAME_THEOR.html

Lin-lin L, Zhong-ying Q (2008). Cheap talk of supply-demand Games in the World Oil Market. International Conference on Management Science and Engineering (ICMSE 2008), 15th Annual Conference Proceedings, 1373-1378, Long Beach, USA

Madani K (2010) Game theory and water resources. J Hydrol 381(3-4):225-238

Madani K, Hipel KW (2007). Strategic Insights into the Jordan River Conflict. Proceeding of the 2007 World Environmental and Water Resources Congress, Tampa, Florida, American Society of Civil Engineers (ASCE), 1-10

Madani K, Hipel KW (2011) Non-cooperative stability definitions for strategic analysis of generic water resources conflicts. Water Resour Manage 25(8):1949-1977

Madani K, Rheinheimer D, Elimam L, Connell-Buck C (2011). A Game Theory approach to understanding the Nile River Basin Conflict. Division of Water Resources Engineering No.3253, 97-114, Lund University, Sweden, ISBN 978-91-7473-221-4, viewed on March 11, 2012. http://www.tvrl.lth.se/fileadmin/tvrl/ files/lb_day/97-114_Festskr.pdf

Magirou VF (1984) Switching away from oil: a game-theoretic approach. Resour Energy 6(4):397-410

Massol O, Tchung-Ming S (2010) Cooperation among liquefied natural gas suppliers: is rationalization the sole objective? Energy Econ 32(4):933-947

Mehr News (2010) Iraq should pay war reparations to Iran from joint oil field profits. News ID 2828546. http://en.mehrnews.com/ news/37794/Iraq-should-pay-war-reparations-to-Iran-from-jointoil-field. Accessed 29 July 2015

Mehr News (2011) Arabic tent in 28 common oil and gas fields: Arabs take away Iran's oil. Mehr News Agency. http://www.mehrnews. $\mathrm{com} / \mathrm{fa} /$ newsdetail.aspx?NewsID $=1360901$. Accessed 22 April 2012 (In Persian)

Murphy F, Oliveira FS (2010) Developing a market-based approach to managing the US strategic petroleum reserve. Eur J Oper Res 206(2):488-495

Press TV News (2012a). Iran signs South Pars drilling deal. Viewed on June 12, 2012. http://www.presstv.ir/detail/218957.html

Press TV News (2012b). Iran, Iraq set up technical teams to develop joint oil fields. Viewed on March 29, 2012. http://www.presstv. ir/detail/231687.html

Nowak AS (2006) A multigenerational dynamic game of resource extraction. Math Soc Sci 51(3):327-336

OPEC-Organization of the Petroleum Exporting Countries (2010-2011). OPEC Annual Statistical Bulletin 2010-2011. 16-17, viewed on March 5, 2012. http://www.opec.org/opec_ web/static_files_project/media/downloads/publications/ ASB2010_2011.pdf

Ostrom E, Gardner R, Walker J (1994) Rules games and commonpool resources. University of Michigan Press, Michigan

Pagliero M (2003) Strategic interaction on the UK Gas Transportation System: the St. Fergus and Bacton constraints. Energy Econ 25(4):345-358

Reuters (2009). Iraq demands Iran withdraw troops from oil field. Viewed on June 24, 2012. http://www.reuters.com/article/2009/ 12/18/us-iraq-iran-idUSTRE5BH1Y920091218
Reynolds DB (1999) Modeling OPEC behavior: theories of risk aversion for oil producer decisions. Energy Policy 27(15):901-912

RFI-Radio France International (2009). Iran/Iraq: Phone conversation of the ministers of foreign affairs. Viewed on August 10, 2012. http:// www.rfi.fr/actufa/articles/120/article_10013.asp. (In Persian)

Ross WD (2010). Game Theory. The Stanford Encyclopedia of Philosophy (fall 2011 Edition), viewed on March 5, 2012. http:// plato.stanford.edu/archives/fall2011/entries/game-theory

Schirillo S (2006). Russian Gas to Western Europe-A Gametheoretic Analysis. Diploma thesis, Socioeconomic Institute, University of Zurich, Swiss, May 2006. Viewed on January 13, 2012. http://www.ce.utexas.edu/prof/maidment/grad/schneider/ WaterResourceManagement/WaterResources.ppt

Schneider K (2001). Water Resources and International Conflict: Game Theory. Power Point Presentation, viewed on March 4, 2012. http://staff.vwi.unibe.ch/industrieoekonomik/paper/ Referat\%20Zweifel.pdfwww.ce.utexas.edu/prof/maidment/grad/ schneider/WaterResourceManagement/WaterResources.ppt

Sheikhmohammady M, Madani K, Bahrini A, Tahmasebi A, Behmanesh I (2011). Modeling and analysis of the conflict over the Triple Islands in the Persian Gulf, Proceeding of the 2011 IEEE International Conference on Systems, Man, and Cybernetics (SMC), IEEE, Anchorage, Alaska, 3046-3050

Shenoy PP (1980a) A two-person non-zero-sum game model the world oil market. Appl Math Model 4(4):295-300

Shenoy PP (1980b) A three-person cooperative game formulation of the world oil market. Math Model 4(4):301-307

Shor M (2005a). Game. Dictionary of Game Theory Terms, viewed on March 5, 2012. http://www.gametheory.net/dictionary/Game. html

Shor M (2005b). Stag Hunt. Dictionary of Game Theory Terms, viewed on April 4, 2013. http://www.gametheory.net/dictionary/ Games/StagHunt.html

Tala News (2013). Why "South Pars" do not contribute oil?. Viewed on January 26, 2015. http://www.talanews.com/fa/\%DA\%86\% D8\%B1\%D8\%A7-\%D9\%BE\%D8\%A7\%D8\%B1\%D8\%B3-\%D 8\%AC\%D9\%86\%D9\%88\%D8\%A8\%DB\%8C-\%D9\%86\%D9\% 81\%D8\%AA-\%D9\%86\%D9\%85\%DB\%8C\%E2\%80\%8C\%D8 \%AF\%D9\%87\%D8\%AF\%D8\%9F-13633.html. (In Persian)

The New York Times (2009). Iran-Iraq Standoff over Oil Field Ends. By T. Williams and D. Adnan. Viewed on March 27, 2012. http://www.nytimes.com/2009/12/21/world/middleeast/21iraq. html

Turocy TL, Von Stengel B (2001). An Introductory Survey of Game Theory. Prepared for the Encyclopedia of Information Systems, Academic Press, CDAM Research Report LSE-CDAM-2001-09, viewed on March 5, 2012. http://www.cdam.lse.ac.uk/Reports/ Files/cdam-2001-09.pdf

Wiszniewska-Matyszkiel A (2008) Common resources, optimality and taxes in dynamic games with increasing number of players. J Math Anal Appl 337(2):840-861

Yang Z (2008) How Does ANWR Exploration Affect OPEC Behavior? - A simulation study of an open-loop Cournot-Nash Game. Energy Econ 30(2):321-332

Zweifel P, Krey B (2009) Russian gas to Western Europe: a gametheoretic analysis. J Energy Mark 2(4):3-28 